Historic, Archive Document

Do not assume content reflects current scientific knowledge, policies, or practices. 


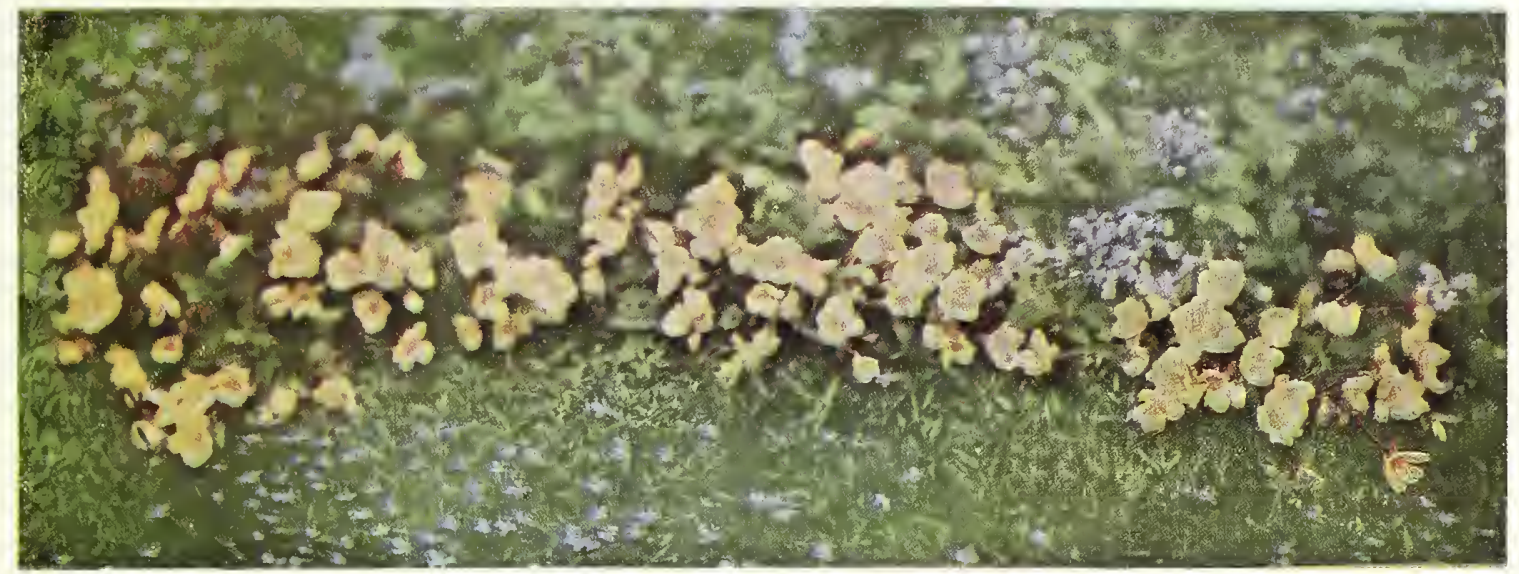

\section{A Begonia that thrives in Strong Sunlight}

\section{"FRAU HELENE HARMS"}

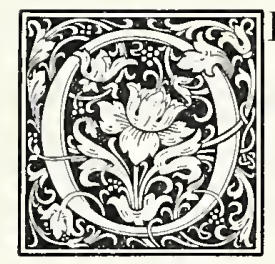

RIGINALLY introduced into this country in $19 \mathrm{IO}$. This begonia will grow equally well in pots, greenhouse, house conservatory, or out of doors in the open border. Tuberous rooted; foliage dark green, of rank growth, with small leaves and flowers freely with blossoms about the size of a half dollar. Full grown plants are about eight inches in height. Flowers out of doors are a beautiful clear orange color, in-door or under glass, a light yellow. Thus far the stock has been remarkably free from disease, and will stand up under long continued wet weather. If beaten down by heavy rain and wind storms a few hours of sunshine will revive the plant and blooms. An unusual feature of this begonia is the fact that the strongest sunshine has no effect upon it, except to promote the groweth of the plant and blooms.

"Frau Helene Harms" was awarded first class certificate of merit by the Massachusetts Horticultural Society in 1920 . In I 92 I it was awarded a silver medal by the same society.

The amount of propagating stock available is limited. If ordered now, we will be able to furnish well grown and rooted plants in April and May, I922. These plants will be in $21 / 2$ inch paper pots, securely packed with full cultural directions. We will insure their safe arrival. They will be about ready to bloom, or beginning to bloom, when received, and, if accorded the usual treatment for tuberous begonias, "Frau Helene Harms" will continue to bloom from May till Thanksgiving under glass, and out of doors from May until the first killing frost.

Orders for delivery in April or May, I 922, should be placed now, as we shall only propagate enough plants to cover our actual orders.

Prices: \$I.50 each; \$ 5.00 per dozen; \$I00.00 per I 00 An Order Blank and Return Envelope are enclosed for your convenience

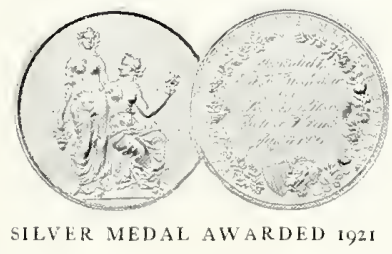

\section{JOSEPH BRECK \& SONS CORPORATION}

5 I NORTH MARKET STREET, BOSTON, MASS. 


\section{Joseph Breck \&}

EVERYTHING

Farm Gardendlawn Joseph BReck \& Sons Corporatos Estasessed fon Boston

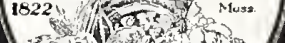

Sons Corporation 